Jurnal Riset Agama

Volume 1, Nomor 2 (Agustus 2021): 389-400

DOI: $10.15575 /$ jra.v1i2.14689

https://journal.uinsgd.ac.id/index.php/jra

\title{
Daun Zaitun dalam Pengobatan Sakit Gusi: Studi Takhrij dan Syarah Hadis
}

\author{
Dinar Siti Nur Aisyah \\ Jurusan Ilmu Al-Qur'an dan Tafsir, Fakultas Ushuluddin \\ UIN Sunan Gunung Djati Bandung, Indonesia \\ dinarsna@gmail.com
}

\begin{abstract}
This study aims to discuss about olive leaf as a medicine for sore gums. This study uses a qualitative type of method that emphasizes literature study through the takhrij and syarah hadith methods with contemporary analysis. The results of this study indicate that the quality status of the hadith about olive leaf as a medicine for gum disease is considered authentic based on the takhrij hadith. And the hadith syarah shows that olive leaf is a medicine for gum pain which in olive leaf contains antimicrobials that are able to overcome infections that cause swollen gums and olive leaf is also analgesic so it is effective in relieving pain. This study concludes that the hadith about olives is acceptable (maqbul) so that it can be used as evidence for Islamic practice. This study recommends accessing information from the Prophet's hadith about olive leaf for the development of gum disease medicine in the medical world.
\end{abstract}

Keywords: Gum; Leaves; Olive; Treatment.

\begin{abstract}
Abstrak
Penelitian ini bertujuan untuk membahas tentang daun zaitun sebagai obat untuk sakit gusi. Penelitian ini menggunakan metode jenis kualitatif yang ditekankan pada studi pustaka melalui metode takhrij dan syarah hadis dengan analisis kontemporer. Hasil penelitian ini menunjukan bahwa status kualitas hadis tentang daun zaitun sebagai obat untuk sakit gusi dinilai shahih berdasarkan takhrij hadis. Dan syarah hadis menunjukan bahwa daun zaitun sebagai obat sakit gusi yang mana di dalam daun zaitun terkandung antimikroba yang mampu mengatasi infeksi yang menyebabkan gusi bengkak serta daun zaitun juga bersifat analgesik sehingga efektif meredakan rasa sakit. Penelitian ini menyimpulkan bahwa hadis tentang zaitun dapat diterima (maqbul) sehingga dapat digunakan menjadi hujah amalan Islam. Penelitian ini
\end{abstract}


Jurnal Riset Agama, Volume 1, Nomor 2 (Agustus 2021): 389-400

Dinar Siti Nur Aisyah / Daun Zaitun dalam Pengobatan Sakit Gusi:

Studi Takhrij dan Syarah Hadis

merekomendasikan untuk mengakses informasi dari hadis Nabi Saw tentang daun zaitun bagi pengembangan obat sakit gusi di dunia medis.

Kata kunci: Daun; Gusi; Pengobatan; Zaitun.

\section{Pendahuluan}

Zaitun merupakan pohon yang memiliki segudang manfaat, mulai dari buah, kayu, daun, dan minyaknya untuk penyembuhan berbagai penyakit (Firmansyah, 2018). Pohon zaitun sendiri merupakan pohon yang selalu berdaun sepanjang tahun; umurnya pun dapat mendekati seribu tahun. Pohon ini berasal dari Oleaceae, negara-negara kawasan Mediterania dan Asia Barat banyak menanam pohon ini (Badwilan, 2010). Akhir-akhir ini diketahui bahwa banyak jenis penyakit yang dapat dicegah oleh minyak zaitun, di antaranya serangan jantung, penebalan atau pengerasan dinding pembuluh nadi, dan masih banyak lagi (Ahmad, 2008). Adapun mengenai daun dari pohon zaitun sendiri gemar dipakai oleh masyarakat Yunani Kuno untuk membasuh luka, obat kandung kemih, menurunkan kadar gula darah, dan menurunkan tekanan darah tinggi. Hal tersebut karena daun zaitun mengandung zat anti-mikroba yang sangat efektif melawan bakteri, jamur, dan virus (Khasanah, 2011). Selain itu, jika dikunyah, daun zaitun bermanfaat untuk mengobati sakit gigi, sakit tenggorokan, dan membersihkan mulut (Haryono, 2010). Berdasarkan penelitian tersebut, artinya daun zaitun bermanfaat pula untuk mengobati sakit gusi. Alangkah banyak sekali manfaat yang dapat diambil dari pohon zaitun. Mengenai pohon zaitun ini, Rasulullah saw. juga menyebutnya dengan pohon berkah, artinya, pohon ini diberkati. Namun, apakah keberkahan pohon zaitun tersebut terkait dengan segudang manfaat yang dimilikinya, khususnya dalam pengobatan sakit gusi? Jawaban atas pertanyaan tersebut memerlukan penelitian tentang hadis terkait yang lebih mendalam. Oleh karena itu, kajian takhrij dan syarah terhadap hadis di atas sangat diperlukan guna memberikan jawaban atas pertanyaan peran daun zaitun dalam pengobatan sakit gusi.

Mengenai pohon zaitun sendiri, sudah ada beberapa penelitian yang ditemukan yang semuanya menunjuk pada banyaknya manfaat dari pohon zaitun, seperti penelitian yang dilakukan oleh Sanjani, M. I., \& Darmalaksana, W. (2021), bertajuk "Takhrij and Syarah Hadith of Agrotechnology: Olive Fruit Efficacy Study," pada Gunung Djati Conference Series. Penelitian ini membahas hadis tentang khasiat buah zaitun. Penelitian ini menggunakan pendekatan kualitatif dengan metode takhrij dan syarah hadis melalui analisis agroteknologi. Hasil dan pembahasan 
Jurnal Riset Agama, Volume 1, Nomor 2 (Agustus 2021): 389-400

Dinar Siti Nur Aisyah / Daun Zaitun dalam Pengobatan Sakit Gusi:

Studi Takhrij dan Syarah Hadis

penelitian ini menunjukkan bahwa status hadis tentang buah zaitun berkualitas sahih, dan buah zaitun ditemukan memiliki khasiat bagi tubuh. Penelitian ini menyimpulkan bahwa analisis agroteknologi dapat digunakan bagi pengembangan khasiat buah zaitun (Sanjani \& Darmalaksana, 2021). Kemudian pada penelitian yang dilakukan oleh Shahilah, R. A. A. R., Darmalaksana, W., \& Rachmawati, Y. S. (2021), dengan tajuk "Takhrij and Syarah Hadith of Agrotechnology: Ingredients and Benefits of Olive Oil," masih pada Gunung Djati Conference Series. Penelitian ini berhasil menemukan analisis pembahasan kandungan dan manfaat minyak zaitun perspektif hadis. Pendekatan yang digunakan di dalamnya yaitu pendekatan kualitatif dengan metode takhrij dan syarah hadis melalui analisis agroteknologi. Adapun hasil dan pembahasan penelitian ini menunjukkan bahwa kualitas hadis tentang zaitun menempati status sahih, dan buah zaitun ditemukan memiliki kandungan yang dapat menghasilkan minyak bagi penyembuhan penyakit tanpa menimbulkan efek samping. Penelitian ini menyimpulkan bahwa analisis agroteknologi dapat digunakan bagi pengembangan kandungan dan manfaat minyak zaitun (Shahilah et al., 2021). Selain itu, Solehah, P. N. H., Darmalaksana, W., \& Firmansyah, E. (2021), dalam penelitian bertajuk "Takhrij and Syarah Hadith of Agrotechnology: Olive Fruit Efficacy Study," pada Gunung Djati Conference Series. Penelitian ini menjelaskan peranan buah zaitun bagi kesehatan menurut hadis. Penelitian ini juga menggunakan pendekatan kualitatif dengan metode takhrij dan syarah hadis melalui analisis agroteknologi. Hasil dan pembahasan penelitian ini menunjukkan bahwa hadis tentang zaitun dinilai berkualitas sahih, dan pohon zaitun ditemukan memiliki buah, daun, dan minyak yang dapat digunakan sebagai anti infeksi organ dalam, seperti ginjal, empedu, dan mengandung senyawa koloid yang dapat membunuh sel-sel kanker. Penelitian ini menyimpulkan bahwa analisis agroteknologi dapat digunakan bagi pengembangan pohon zaitun bagi pengobatan di zaman modern (Solehah et al., 2021).

Menindak lanjuti ketiga tinjauan di atas, disusun suatu kerangka berpikir bahwa zaitun disebut dengan pohon berkah oleh hadis Nabi saw., sebagaimana sudah dijelaskan sebelumnya. Keberkahan tersebut terpancar dari banyaknya manfaat yang dimiliki pohon zaitun, salah satunya adalah untuk pengobatan sakit gusi. Hadis sebagaimana dipahami dalam bentuk apapun yang berasal dari Rasulullah Saw. (Darmalaksana, 2018) dipahami sebagai sumber Islam kedua setelah alQur'an (Darmalaksana et al., 2017). Status hadis sendiri beragam sehingga kualitasnya perlu diteliti melalui ilmu takhrij hadis. Menurut ilmu hadis, takhrij ialah mengeluarkan hadis dari kitab hadis untuk diketahui statusnya meliputi kualitas dhaif, hasan, dan sahih (Darmalaksana, 2020c). Selebihnya, perlu dilakukan syarah untuk mengetahui kandungan teks 
Jurnal Riset Agama, Volume 1, Nomor 2 (Agustus 2021): 389-400

Dinar Siti Nur Aisyah / Daun Zaitun dalam Pengobatan Sakit Gusi:

Studi Takhrij dan Syarah Hadis

hadis dari berbagai pendekatan (Darmalaksana, 2020b). Sementara itu, hadis tentang zaitun digunakan dalam penelitian ini ditemukan dalam beberapa kitab hadis dengan status kualitas sahih (Sanjani \& Darmalaksana, 2021; Shahilah et al., 2021; Solehah et al., 2021). Hadis sahih berarti dapat diterima (maqbul) dan dapat diamalkan ( $m a^{\prime} m u l b i h$ ) dalam amalan Islam (Darmalaksana, 2018). Hadis tentang zaitun juga telah dijelaskan dari sisi agroteknologi (Sanjani \& Darmalaksana, 2021; Shahilah et al., 2021; Solehah et al., 2021), kimia (Humaira \& Qodim, 2021), farmasi (Dalil, 2017), dan lain-lain. Zaitun sendiri merupakan pohon istimewa yang penuh berkah sebagaimana disinggung dalam al-Qur'an (Nisak, 2018; Sopiah, 2019). Pohon, daun dan buah zaitun dapat diekstrak menjadi minyak (Shahilah et al., 2021) yang memiliki banyak manfaat bagi kesehatan tubuh (Solehah et al., 2021). Antara lain dari berbagai manfaat kesehatan tersebut disinggung bahwa olahan buah zaitun berguna bagi pengobatan infeksi bakteri radang gusi (Widianti, 2017).

Mengacu pada seluruh pemaparan di atas, susunan formula penelitian ini adalah sebagai berikut: rumusan masalah penelitian, pertanyaan utama penelitian, dan tujuan penelitian (Darmalaksana, 2020b). Rumusan masalah penelitian ini yaitu terdapat syarah hadis tentang daun zaitun dalam pengobatan sakit gusi. Pertanyaan utama penelitian ini yaitu bagaimana syarah hadis tentang daun zaitun dalam pengobatan sakit gusi. Pertanyaan utama tersebut memunculkan pertanyaan-pertanyaan terperinci, yaitu, bagaimana teks hadis tentang zaitun, bagaimana kualitas hadis tentang zaitun, dan bagaimana syarah hadis tentang daun zaitun dalam pengobatan sakit gusi. Sementara itu, tujuan penelitian ini yaitu membahas hadis tentang daun zaitun dalam pengobatan sakit gusi. Adapun manfaat dari hasil yang diperoleh dari penelitian ini mencakup manfaat teoritis dan manfaat praktis (UIN Sunan Gunung Djati Bandung, 2020). Manfaat teoritis penelitian ini berupa penambahan wawasan para pengkaji hadis terkait syarah hadis tentang pohon zaitun. Sedangkan manfaat praktisnya berupa penambahan wawasan bagi masyarakat umum tentang manfaat daun zaitun untuk pengobatan sakit gusi berdasarkan petunjuk hadis.

\section{Metode Penelitian}

Jenis penelitian yang digunakan dalam artikel ini adalah jenis kualitatif melalui studi pustaka (Darmalaksana, 2020a). Adapun metode yang digunakan dalam penelitian ini berupa pengaplikasian metode takhrij dan syarah (Darmalaksana, 2020b) pada hadis yang menerangkan pohon zaitun dengan analisis kontemporer (Darmalaksana, 2020b), terutama dalam pengobatan sakit gusi. 
Jurnal Riset Agama, Volume 1, Nomor 2 (Agustus 2021): 389-400

Dinar Siti Nur Aisyah / Daun Zaitun dalam Pengobatan Sakit Gusi:

Studi Takhrij dan Syarah Hadis

\section{Hasil dan Pembahasan}

Hasil dan pembahasan penelitian ini akan terbagi dalam beberapa hal sebagai berikut:

\section{Teks Hadis Pohon Zaitun}

Berdasarkan pencarian hadis pada aplikasi Ensiklopedi Hadis Kitab 9 Imam ditemukan satu hadis tentang zaitun yang menjadi objek kajian dalam penelitian ini (Lidwa \& Saltanera, 2010). Hadis tersebut diriwayatkan oleh Ibnu Majah dengan nomor hadis yaitu 3310, kitab tentang makanan pada bab Minyak Samin, sebagai berikut:

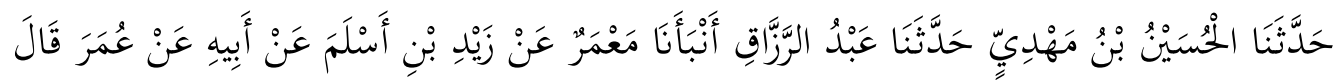

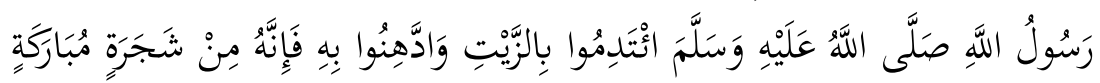

Artinya: Telah menceritakan kepada kami al-Husain bin Mahdi telah menceritakan kepada kami Abdurrazaq telah memberitakan kepada kami Ma'mar dari Zaid bin Aslam dari Ayahnya dari Umar dia berkata, "Rasulullah bersabda, "Jadikanlah minyak (zaitun) sebagai lauk paukmu, dan minyakilah (rambut) kalian dengannya, sesungguhnya ia berasal dari pohon yang berkahi" (Hadis No. 3310 HR. Ibnu Majah) (Lidwa \& Saltanera, 2010).

\section{Takhrij Hadis tentang Pohon Zaitun}

Takhrij hadis tentang pohon zaitun di atas adalah sebagai berikut (Lidwa \& Saltanera, 2010):

Tabel 1. Daftar Rawi Sanad

\begin{tabular}{|c|c|c|c|c|c|c|c|}
\hline \multirow[t]{2}{*}{ No. } & \multirow[t]{2}{*}{ Rawi Sanad } & \multicolumn{3}{|c|}{ Lahir/ } & \multirow[t]{2}{*}{ Kuniyah } & $\begin{array}{l}\text { Komentar } \\
\text { Ulama }\end{array}$ & \multirow[t]{2}{*}{ Kalangan } \\
\hline & & $\mathrm{L}$ & W & & & + & \\
\hline 1 & $\begin{array}{l}\text { Umar bin al- } \\
\text { Khaththab } \\
\text { bin Nufail }\end{array}$ & & $\begin{array}{l}23 \\
\mathrm{H}\end{array}$ & Madinah & Abu Hafsh & Sahabat & Sahabat \\
\hline 2 & $\begin{array}{l}\text { Aslam } \\
\text { maula } \\
\text { Unmar }\end{array}$ & & $\begin{array}{l}80 \\
\mathrm{H}\end{array}$ & Madinah & $\begin{array}{l}\text { Abu } \\
\text { Khalid }\end{array}$ & $\begin{array}{l}\text { Al-`Ajli: } \\
\text { Tsiqah, } \\
\text { Abu } \\
\text { Zur`ah } \\
\text { Arrazy: } \\
\text { Tsiqah, } \\
\text { Ya`kub } \\
\text { Ibnu } \\
\text { Syaibah: }\end{array}$ & $\begin{array}{l}\text { Tabi'in } \\
\text { kalangan } \\
\text { tua }\end{array}$ \\
\hline
\end{tabular}


Jurnal Riset Agama, Volume 1, Nomor 2 (Agustus 2021): 389-400

Dinar Siti Nur Aisyah / Daun Zaitun dalam Pengobatan Sakit Gusi:

Studi Takhrij dan Syarah Hadis

\begin{tabular}{|c|c|c|c|c|c|c|}
\hline & & & & & $\begin{array}{l}\text { Tsiqah, } \\
\text { Ibnu } \\
\text { Hibban: } \\
\text { disebutkan } \\
\text { dalam `ats } \\
\text { tsqiaat }\end{array}$ & \\
\hline 3 & $\begin{array}{l}\text { Zaid bin } \\
\text { Aslam }\end{array}$ & $\begin{array}{c}136 \\
\mathrm{H}\end{array}$ & Madinah & $\begin{array}{l}\text { Abu } \\
\text { Usamah }\end{array}$ & $\begin{array}{l}\text { Ahmad bin } \\
\text { Hambal: } \\
\text { Tsiqah, } \\
\text { Abu } \\
\text { Zur`ah } \\
\text { Arrazy: } \\
\text { Tsiqah, } \\
\text { Abu Hatim } \\
\text { Ar-Rozy: } \\
\text { Tsiqah, } \\
\text { Muhamma } \\
\text { d bin Sa`d: } \\
\text { Tsiqah, } \\
\text { Ya`kub } \\
\text { Ibnu } \\
\text { Syaibah: } \\
\text { Tsiqah; } \\
\text { An- Nasa`i: } \\
\text { Tsiqah, } \\
\text { Adz- } \\
\text { Dzahabi: } \\
\text { Ahli fiqih }\end{array}$ & $\begin{array}{l}\text { Tabi'in } \\
\text { kalangan } \\
\text { pertengaha } \\
\mathrm{n}\end{array}$ \\
\hline 4 & $\begin{array}{l}\text { Ma`mar bin } \\
\text { Raosyid }\end{array}$ & $\begin{array}{c}154 \\
\mathrm{H}\end{array}$ & Yaman & $\begin{array}{l}\text { Abu } \\
\text { 'Urwah }\end{array}$ & $\begin{array}{l}\text { Yahya bin } \\
\text { Ma`in: } \\
\text { Tsiqah, Al- } \\
\text { `Ajli: } \\
\text { Tsiqah, } \\
\text { Ya`kub bin } \\
\text { Syu`bah: } \\
\text { Tsiqah, } \\
\text { Abu } \\
\text { Hatim: } \\
\text { Shalihul } \\
\text { hadits, An- } \\
\text { Nasa`i: } \\
\text { Tsiqah } \\
\text { ma`mun, } \\
\text { Ibnu } \\
\text { Hibban: } \\
\text { Disebutkan } \\
\text { dalam `ats- } \\
\text { tsiqaat, } \\
\text { Ibnu Hajar } \\
\text { al- } \\
\text { `Asqalani: }\end{array}$ & $\begin{array}{l}\text { Tabi ut } \\
\text { Tabi in } \\
\text { kalangan } \\
\text { tua }\end{array}$ \\
\hline
\end{tabular}


Jurnal Riset Agama, Volume 1, Nomor 2 (Agustus 2021): 389-400

Dinar Siti Nur Aisyah / Daun Zaitun dalam Pengobatan Sakit Gusi:

Studi Takhrij dan Syarah Hadis

\begin{tabular}{|c|c|c|c|c|c|c|c|}
\hline & & & & & & $\begin{array}{l}\text { Tsiqah } \\
\text { tsabat }\end{array}$ & \\
\hline 5 & $\begin{array}{l}\text { Abdur } \\
\text { Razzaq bin } \\
\text { Hammam } \\
\text { bin Nafi }\end{array}$ & & $\begin{array}{c}211 \\
\mathrm{H}\end{array}$ & Yaman & Abu Bakar & $\begin{array}{l}\text { Abu Daud: } \\
\text { Tsiqah, Al- } \\
\text { `Ajli: } \\
\text { Tsiqah, } \\
\text { tertuduh } \\
\text { beraliran } \\
\text { syi`ah, An- } \\
\text { Nasa`i: } \\
\text { Tsabat, } \\
\text { Ya`kub bin } \\
\text { Syaibah: } \\
\text { Tsiqah } \\
\text { tsabat, } \\
\text { Ibnu } \\
\text { Hibban: } \\
\text { Tsiqah, } \\
\text { Ibnu`Adi: } \\
\text { La ba`sa } \\
\text { bih, Ibnu } \\
\text { Hajar al- } \\
\text { `Asqalani: } \\
\text { Tsiqoh } \\
\text { hafidz, } \\
\text { Adz- } \\
\text { Dzahabi: } \\
\text { seorang } \\
\text { tokoh }\end{array}$ & $\begin{array}{l}\text { Tabi ut } \\
\text { Tabi in } \\
\text { kalangan } \\
\text { biasa }\end{array}$ \\
\hline 6 & $\begin{array}{l}\text { Al-Husain } \\
\text { bin Mahdi } \\
\text { bin Malik }\end{array}$ & & $\begin{array}{c}247 \\
\mathrm{H}\end{array}$ & Basrah & Abu Sa id & $\begin{array}{l}\text { Ibnu Hajar } \\
\text { al- } \\
\text { `Asqalani: } \\
\text { Disebutkan } \\
\text { dalam `ats } \\
\text { tsiqaat, } \\
\text { Abu } \\
\text { Hatim: } \\
\text { Shaduuq, } \\
\text { Ibnu Hajar } \\
\text { al- } \\
\text { `Asqalani: } \\
\text { Shaduuq }\end{array}$ & $\begin{array}{l}\text { Tabi 'ul } \\
\text { Atba` } \\
\text { kalangan } \\
\text { pertengaha } \\
\text { n }\end{array}$ \\
\hline 7 & $\begin{array}{l}\text { Muhammad } \\
\text { bin Yazid } \\
\text { bin Majah al- } \\
\text { Qazwini }\end{array}$ & $\begin{array}{c}824 \\
M\end{array}$ & $\begin{array}{c}887 \\
M\end{array}$ & Qazwin & $\begin{array}{l}\text { Abu } \\
\text { 'Abdullah }\end{array}$ & $\begin{array}{l}\text { Imam } \\
\text { hadits }\end{array}$ & Mudawin \\
\hline
\end{tabular}

Tabel di atas merupakan daftar rawi dan sanad hadis yang diriwayatkan oleh Ibnu Majah dengan nomor hadis 3310 Bab Minyak 
Jurnal Riset Agama, Volume 1, Nomor 2 (Agustus 2021): 389-400

Dinar Siti Nur Aisyah / Daun Zaitun dalam Pengobatan Sakit Gusi:

Studi Takhrij dan Syarah Hadis

Samin. Tabel ini memiliki matrik rawi-sanad, tahun wafat dan lahir, negeri, kuniyah (panggilan), komentar ulama, dan kalangan. Hadis ini diriwayatkan oleh 7 (tujuh) orang rawi (periwayat), sejak asal sanad (rawi pertama) yaitu Umar bin al-Khaththab bin Nufail (kalangan sahabat) sampai mudawin (rawi terakhir) Muhammad bin Yazid bin Majah alQazwini yang dikenal Ibnu Majah (824-887 H). Semua rawi diketahui kuniyahnya dan tidak ada satupun dari periwayat yang diketahui kelahirannya. Mengacu pada ilmu hadis bahwa rawi pertama merupakan sanad terakhir dan rawi terakhir merupakan sanad pertama (Darmalaksana, 2020b).

\section{Kualitas Hadis tentang Pohon Zaitun}

Hadis dikatakan berkualitas sahih apabila rawi adil dan dhabit, sanad bersambung (muttasil), matan hadis tidak janggal (syadz), dan matan hadis tidak cacat (Darmalaksana, 2018). Pada tabel 1 tampak bahwa menurut Muhammad Nashiruddin al-Albani hadis ini adalah shahih. Dalam hadis ini banyak para ulama yang memberi komentar positif terhadap para rawi dengan memberi komentar tsiqah. Tsiqah adalah orang yang diberi kepercayaan oleh orang lain, dalam hal agama, perilaku, dan akal (Ahmad bin Tsabit bin Said Al-Wushoby, 2012). Komentar ulama pun sangat beragam cakupannya ada yang menilai positif ( $t$ ' dill) dan ada pula yang menilai negatif (jarh) (Darmalaksana, 2021b). Rawi yang dinilai tsiqah berarti ia merupakan orang yang adil dan kuat hafalannya. Selain tsiqah para ulama juga memberi komentar ahli fiqih, at tsiqaat, shalihul hadist, tsiqah tsabat, tsiqah ma'mun, tsabat, la ba`sa bih, tsiqah hafidz dan shaduuq. Kemudian tidak ada satu pun komentar ulama yang berkomentar negatif pada Tabel 1 terhadap para rawi tersebut. Kecuali, Abdur Razzaq bin Hammam bin Nafi (w. 211 H.) dinilai oleh al-`Ajli yakni tsiqah tertuduh beraliran Syiah yang seharusnya masuk pada kategori negatif. Namun, bila terdapat periwayat tertuduh beraliran tertentu sejauh hadis yang diriwaykan tidak berkenaan dengan masalah aqidah, maka hadis tersebut dapat diterima (Alis, 2017). Maka dengan ini dapat disimpulkan bahwa rawi dalam jalur sanad ini seluruhnya adalah adil dan kuat hafalannya yang dapat mempengaruhi kualitas hadis. Sedangkan syarat sanad bersambung adalah bertemu (liqa') antara guru (yang menyampaikan hadis) dan murid (yang menerima hadis) (Darmalaksana, 2018). Pertemuan antara guru dan murid dapat diketahui dari masa waktu dan negeri. Masa waktu dapat dilihat dari tahun lahir, tahun wafat dan negeri dapat menunjukan pertemuan guru dan murid di satu wilayah (Darmalaksana, 2020c).

Apabila beberapa periwayat tidak diketahui tahun lahir dan wafat, maka para rawi tersebut dapat diasumsikan rata-rata berusia kurang lebih 90 tahun (Darmalaksana, 2021a). Oleh karena itu, pada Tabel 1 
Jurnal Riset Agama, Volume 1, Nomor 2 (Agustus 2021): 389-400

Dinar Siti Nur Aisyah / Daun Zaitun dalam Pengobatan Sakit Gusi:

Studi Takhrij dan Syarah Hadis

diperkirakan bertemu antara guru dan murid. Dengan kata lain, sanad hadis pada Tabel 1 dikatakan bersambung (muttasil) (Firdaus, 2015).

Selain dilihat dari penilaian rawi dan sanad, kualitas hadis ditentukan dari segi matan dengan syarat terhindar dari kejanggalan dan cacat (syadz). Bahwa tidak terdapat kejanggalan dan cacat dalam hadis ini maka dari itu dapat disimpulkan hadis riwayat Ibnu Majah No. 3310 dapat dikatakan sebagai hadis yang shahih. Hadis mengenai buah zaitun ini selain bernilai shahih juga memberi manfaat salah satunya dalam pengobatan sakit gusi dan buah zaitun ini sangat layak untuk dikonsumsi. Dari sanad ke-1 sampai sanad ke-6, ialah tersambung. Maksudnya para perawi dipercaya menerima hadits tentang buah zaitun dari Nabi SAW. Dari adanya persambungan ini jelas bahwa hadits tersebut dilihat dari kualitas sanad ialah bernilai shahih. Sedangkan, dari sudut matan hadits ini, tidak ada yang bertentangan dengan tolak ukur kesahihan matan.

\section{Syarah Hadis Daun Zaitun dalam Pengobatan Sakit Gusi}

Syarah merupakan penjelasan tentang hadits, begitu pula syarah yang berkaitan dengan hadis merupakan usaha menafsirkan makna yang ada di balik teks hadis (Darmalaksana, 2020b). Hadis yang bisa diamalkan (ma`mul) dan haditsnya telah diterima (maqbul) melalui takhrij (Darmalaksana, 2018). Berdasarkan takhrij ditemukan status hadis riwayat Ibnu Majah No. 3310 berkualitas shahih dari sisi tersambungnya sanad dan dari penilaian rawi yang mana hadis dapat diterima, adil dan dhabit periwayatnya, dan dari segi matannya tidak ada kejanggalan dan cacat.

Hadis riwayat Ibnu Majah No. 3310 memberi keterangan bahwa hadits mengenai buah zaitun ini selain bernilai shahih juga memberi petunjuk bahwa perlunya kesediaan buah zaitun dalam setiap rumah atau keluarga. Hadis ini juga memiliki hujah yang kuat dan memiliki nalar untuk menguak pemahaman hadis. Terlebih buah zaitun ini sangat banyak sekali khasiatnya salah satunya adalah daun zaitun yakni untuk pengobatan sakit gusi karena antimikroba yang terkandung dalam daun zaitun mampu mengatasi infeksi yang menyebabkan gusi bengkak (Widianti, 2017). Tak hanya itu, daun zaitun juga bersifat analgesik sehingga efektif meredakan rasa sakit. Selain untuk pengobatan sakit gusi khasiat yang lain dari zaitun ini adalah dalam minyak zaitun yang bisa menurunkan resiko penyakit jantung, kanker, meningkatkan sistem kekbalan tubuh, melindungi dari diabetes, melawan lemak, memperlambat proses penuaan dan masih banyak lagi khasiat dari minyak zaitun ini (Cal Orey, 2008; Dalil, 2017; Humaira \& Qodim, 2021; Nisak, 2018; Sanjani \& Darmalaksana, 2021; Shahilah et al., 2021; Solehah et al., 2021; Sopiah, 2019).

Khasiat buah zaitun dinformasikan berdasarkan hadis Nabi Saw dan telah dipraktikan di masa beliau sejak ribuan tahun yang lalu. Informasi 
Jurnal Riset Agama, Volume 1, Nomor 2 (Agustus 2021): 389-400

Dinar Siti Nur Aisyah / Daun Zaitun dalam Pengobatan Sakit Gusi:

Studi Takhrij dan Syarah Hadis

ini hingga di masa sekarang membawa manfaat besar bagi pengembangan di dunia kedokteran modern. Secara khusus, daun zaitun ini diakui berkhasiat bagi pengobatan sakit gusi menurut penelitian di era modern. Di sini arti penting menggali informasi berdasarkan hadis dikaitkan dengan kemajuan ilmu pengetahuan dan teknologi di masa sekarang.

\section{Kesimpulan}

Daun zaitun merupakan obat untuk menyembuhkan sakit gusi karena di dalamnya terkandung antimikroba yang terkandung dalam daun zaitun mampu mengatasi infeksi yang menyebabkan gusi bengkak. Tak hanya itu, daun zaitun juga bersifat analgesik sehingga efektif meredakan rasa sakit. Status kualitas hadis tentang daun zaitun sebagai pengobatan sakit gusi dinilai shahih berdasarkan takhrij hadis. Dan syarah hadis menunjukan bahwa daun zaitun sebagai pengobatan sakit gusi yang mana di dalam zaitun ini terkandung banyak khasiat untuk berbagai macam penyakit. Kandungan matan juga tidak bertentangan dengn hadis lain maupun dengan ayat-ayat Al-Qur'an. Dengan demikian hadis dari riwayat Ibn Majah dapat dijadikan hujah. Pemaknaan hadis menunjukkan bahwa isi matan hadis tersebut mengandung anjuran mengkonsumsi dan menggunakan minyaknya untuk bahan pangan yang bermanfaat untuk kesehatan, karena minyak zaitun berasal dari pohan yang di berkahi. Penelitian ini diharapkan memiliki manfaat teoritis bagi penambahan wawasan para pengkaji hadis terkait syarah hadis tentang pohon zaitun dan manfaat praktis sebagai penambahan wawasan bagi masyarakat umum tentang manfaat daun zaitun untuk pengobatan sakit gusi berdasarkan petunjuk hadis. Penelitian ini memiliki keterbatasan dalam pemaparan syarah hadis dari perpektif ilmu kesehatan sehingg terbuka peluang bagi penelitian lebih lanjut untuk menghasilkan kegunaan yang lebih dirasakan manfaatnya. Penelitian ini merekomendasikan kepada para ahli medis untuk melihat petunjuk-petujuk hadis dalam pengembangan dunia kesehatan.

\section{Daftar Pustaka}

Ahmad bin Tsabit bin Said Al-Wushoby. (2012). At-tautsiq wat tadhi f bainal muhadditdin waddu at. 304.

Ahmad, Y. al-H. (2008). Ensiklopedia Kemukjizatan Ilmiah dalam al-Qur'an dan Sunah. Kharisma Ilmu.

Alis, M. K. B. I. N. (2017). Perawi yang Tertuduh sebagai Syiah dalam Shahih al-Bukhari. Universitas Islam Negeri Sultan Syarif Kasim Riau.

Badwilan, A. S. (2010). Manfaat dan Khasiat Minyak Zaitun: Rahasia dan Mukjizat dari Pohon yang Diberkati. Thibia.

Cal Orey. (2008). Khasiat Minyak Zaitun Resep Umur Panjang Ala Mediterania. 
Jurnal Riset Agama, Volume 1, Nomor 2 (Agustus 2021): 389-400

Dinar Siti Nur Aisyah / Daun Zaitun dalam Pengobatan Sakit Gusi:

Studi Takhrij dan Syarah Hadis

Dalil, F. Y. M. (2017). Hadis-Hadis tentang Farmasi: Sebuah Kajian Integratif dalam Memahami Hadis Rasulullah. PROCEEDING IAIN Batusangkar, 1(1), 309-326.

Darmalaksana, W. (2018). Paradigma Pemikiran Hadis. Jurnal Aqidah Dan Filsafat Islam, 2(1), 95-106.

Darmalaksana, W. (2020a). Metode Penelitian Kualitatif Studi Pustaka dan Studi Lapangan. Pre-Print Digital Library UIN Sunan Gunung Djati Bandung.

Darmalaksana, W. (2020b). Penelitian Metode Syarah Hadis Pendekatan Kontemporer: Sebuah Panduan Skripsi, Tesis, dan Disertasi. Diroyah: Jurnal Studi Ilmu Hadis, 5.

Darmalaksana, W. (2020c). Prosiding Proses Bisnis Validitas Hadis untuk Perancangan Aplikasi Metode Tahrij. Jurnal Ushuluddin UIN Sunan Gunung Djati Bandung, 1, 1-7.

Darmalaksana, W. (2021a). Herbal Tumbuhan Senna dalam Pengobatan Infeksi Covid-19: Studi Takhrij dan Syarah Hadis. Pre-Print Kelas Menulis UIN Sunan Gunung Djati Bandung, 19, 1-11.

Darmalaksana, W. (2021b). Kosmetik Halal sebagai Lifestyle untuk Kesehatan: Studi Takhrij Hadis dan Syarah Hadis. 148, 148-162.

Darmalaksana, W., Pahala, L., \& Soetari, E. (2017). Kontroversi Hadis sebagai Sumber Hukum Islam. Wawasan: Jurnal Ilmiah Agama Dan Sosial Budaya, 2(2), 245-258.

Firdaus. (2015). Penelitian Persambungan Sanad Hadis.

Firmansyah, H. (2018). Zaitun dalam Pandangan Alquran dan Sains (Kajian Tafsir 'Ilmy). UIN Sultan Maulana Hasanuddin Banten.

Haryono, Y. (2010). "Zaitun" Pohon KPK (Kesehatan, Perdamaian dan Kejayaan) Penuh Barokah (Issue September, pp. 1-25). Universitas Kajuran Malang.

Humaira, A. F., \& Qodim, H. (2021). Takhrij and Syarah Hadith of Chemistry The Compound Content in Olive and Their Suitability in the Hadith. International Journal of Discoveries and Innovations in Applied Sciences, 1(3), 7-10.

Khasanah, N. (2011). Kandungan Buah-buahan dalam al-Qur'an: Buah Tin (Ficus carica L.), Zaitun (Olea europea L.), Delima (Punica granatum L.), Anggur (Vitis vinivera L.), dan Kurma (Phoenix dactylifera L.) untuk Kesehatan. Jurnal Phenomenom, 1(1).

Lidwa, \& Saltanera. (2010). Ensiklopedi Hadits (9.7.3). Saltanera.

Nisak, K. (2018). Keistimewaan Zaitun dalam Perspektif al-Qur'an dan Sains: Analisis Penafsiran Surah al-Mukminun Ayat 20. UIN Sunan Ampel Surabaya.

Sanjani, M. I., \& Darmalaksana, W. (2021). Takhrij and Syarah Hadith of Agrotechnology: Olive Fruit Efficacy Study. Gunung Djati Conference Series, 1, 36-43. 
Jurnal Riset Agama, Volume 1, Nomor 2 (Agustus 2021): 389-400

Dinar Siti Nur Aisyah / Daun Zaitun dalam Pengobatan Sakit Gusi:

Studi Takhrij dan Syarah Hadis

Shahilah, R. A. A. R., Darmalaksana, W., \& Rachmawati, Y. S. (2021). Takhrij and Syarah Hadith of Agrotechnology: Ingredients and Benefits of Olive Oil. Gunung Djati Conference Series, 1, 396-401.

Solehah, P. N. H., Darmalaksana, W., \& Firmansyah, E. (2021). Takhrij and Syarah Hadith of Agrotechnology: The Role of Olives for Health. Gunung Djati Conference Series, 1, 402-407.

Sopiah, S. (2019). Keistimewaan Zaitun dalam Al-Qur'an Ditinjau dari Perspektif Ilmu Kesehatan. UIN Sunan Gunung Djati Bandung.

UIN Sunan Gunung Djati Bandung. (2020). Pedoman Penulisan Skripsi, Tesis, dan Disertasi. UIN Sunan Gunung Djati Bandung.

Widianti, Z. (2017). Efek antiinflamasi ekstrak etanol daun zaitun (Olea europaea L.) pada edema telapak kaki tikus galur Sprague-Dawley jantan yang diinduksi karagenan 2017. UIN Syarif Hidayatullah Jakarta: Fakultas Kedokteran dan Ilmu Kesehatan, 2017. 